\title{
Elephants and ivory poaching in the forests of equatorial Africa
}

\author{
R. F. W. Barnes, M. Agnagna, M. P. T. Alers, A. Blom, \\ G. Doungoube, M. Fay, T. Masunda, J. C. Ndo Nkoumou, \\ C. Sikubwabo Kiyengo and M. Tchamba
}

\begin{abstract}
Reconnaissance surveys were made of the forests of four central African countries to establish, for the first time, the status of forest-dwelling elephants. The results, when combined with information from previous surveys in other countries, provide a picture of the elephant situation in the forest zone, and especially the impact of poaching. About one-third of the forest elephant population of central Africa is to be found in Zaire, and about one-third in Gabon. The rest are in Cameroon, Central African Republic, Equatorial Guinea, and Congo. It is poaching for ivory, rather than the growth of human populations, which threatens the elephants of the equatorial forests.
\end{abstract}

\section{Introduction}

As the 1989 CITES meeting approached, it became clear that the ivory trade and its impact upon elephants would be a major topic of discussion. But a continental assessment of elephants in relation to the ivory trade was hindered by the absence of information from the equatorial forests. These forests account for about one-third of the range of the African elephant Loxodonta africana (Burrill and Douglas-Hamilton, 1987). Except for a survey of Gabon (WCI, 1989; Barnes et al., 1991) and a brief reconnaissance in Equatorial Guinea (Alers and Blom, 1988), little was known about the abundance and distribution of elephants in the equatorial forests. A review of the available literature had suggested that there was a considerable amount of ivory poaching in the forests (Barnes, 1987). Large quantities of ivory were being exported from central Africa (Parker, 1979; Luxmoore et al., 1989), but there was not enough information to assess the effect of this on elephant trends. Therefore a series of reconnaissances was planned for the forests of Cameroon, Central African Republic (CAR), Congo, and Zaire (Figure 1). These were the countries for which information was most urgently needed.
There were two aims: first, to provide preliminary information on the status of elephants; and second, to furnish the basis for planning detailed sample surveys in the future. In each country the field teams collected information on the abundance and distribution of elephants and the threats they faced, paying particular attention to ivory poaching.

These were preliminary reconnaissances and were not intended to produce accurate estimates of elephant numbers. However, preliminary data were collected to give a rough idea of elephant numbers in each country. The methods and the results for the estimates of elephant numbers are described elsewhere (Barnes and Jensen, 1987; Michelmore et al., 1989; Fay and Agnagna, 1991a, 1991b; Alers et al., in press). Here we present a summary of the situation in the forests of four central African countries and combine this with the results of earlier work in Gabon and Equatorial Guinea to provide a regional perspective of the elephant situation in 1989.

\section{General background}

The central African forests cover large parts of Cameroon, Central African Republic, Congo, 


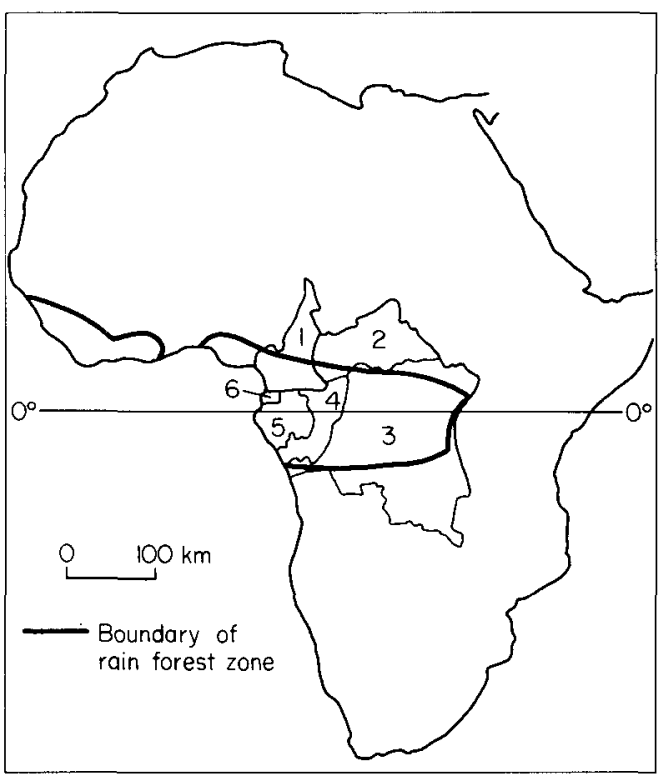

Figure 1. Map of Africa showing the lowland rain forest zone of central Africa (redrawn from White, 1983). 1, Cameroon; 2, Central African Republic (CAR); 3, Zaire; 4, Congo; 5, Gabon; 6, Equatorial Guinea.

Equatorial Guinea, Gabon, and Zaire (Figure 1). The total forest area is about 1.7 million sq $\mathrm{km}$ (FAO/UNEP, 1981). Human populations are sparse; rural population densities are often less than one person per sq $\mathrm{km}$.

Two subspecies of elephant live in these forests, Loxodonta africana africana (the bush or savannah elephant) and Loxodonta africana cyclotis (the forest elephant). In this paper the term 'elephant' or 'forest elephant' covers all elephants dwelling in forests.

\section{Methods}

Most of the field-work was conducted between January 1989 and June 1989, with some further work in Zaire in August and September 1989.

It was impossible to cover more than a tiny fraction of the area in the limited time available. Therefore, in each country the teams made a particular point of reconnoitering the remotest forests with the most sparsely distributed human populations. Other forests were also visited. The teams questioned a wide range of people with experience of the forests: wildlife officers, hunters, missionaries, naturalists, and loggers, as well as other biologists.

\section{Cameroon}

\section{Background}

Forests cover the southern two-fifths of Cameroon. The south-eastern forests are sparsely inhabited, with a human population density of 4 per sq km (Gartlan, 1989). In contrast, the forests to the west and south-west of the capital Yaounde are densely populated. For example, the mean human density in the West Province is 96 people per sq $\mathrm{km}$ (Gartlan, 1989).

\section{Results}

In the far west of the forest zone, close to the Nigerian frontier, some elephants were to be found at low density in the Korup National Park (Figure 2). In the south-west and southcentral forests, which are densely populated and heavily logged, there were few elephants left. Those that remained were found in scattered pockets of forest.

Elephants became more common in the forests east of Sangmelima and Abong Mbang (Figure 2). There was a zone of high elephant density in the extreme south-east corner, adjacent to the frontier with Congo and CAR. Thus the south-eastern forests accounted for a very high proportion of the 15,000 elephants estimated by Michelmore et al. (1989) to remain in Cameroon.

Poaching was common wherever there were elephants. The expansion of the logging industry has opened up new roads, which enable poachers to hunt in areas that were previously difficult to reach. Prominent individuals, such as local government officials, merchants, and loggers, were known to commission pygmies to hunt for ivory and to supply guns and ammunition. In 1987 at least one gang of ivory poachers was operating in the 


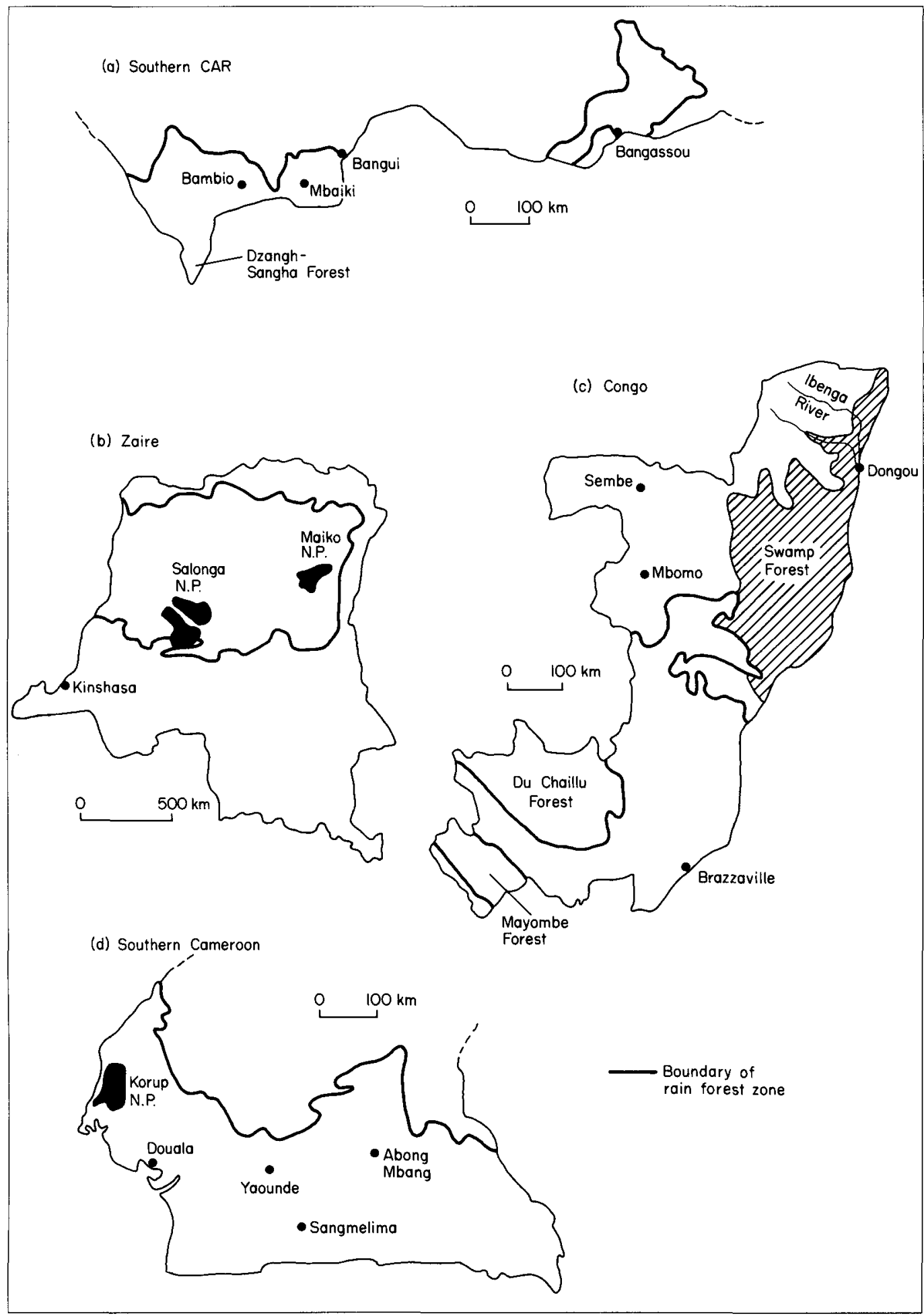

Figure 2. Maps of the forest zones of the Central African Republic, Cameroon, Congo, and Zaire. 
frontier area of northern Gabon, south-eastern Cameroon and north-west Congo.

\section{Central African Republic}

\section{Background}

Most of CAR is covered by woodland and savannah. In this zone poachers killed 80 per cent of the elephants within a few years (Douglas-Hamilton et al., 1985; Froment, 1985).

The forests of south-western CAR are contiguous with those of Cameroon, Congo, and Zaire. There is another block of forest near Bangassou in southern CAR, east of Bangui (Pinglo, 1988). Altogether, forest accounts for only 6 per cent of the country's area.

\section{Results}

The Dzangha-Sangha area was not visited because of the previous work there, which has shown there to be large numbers of elephants (Carroll, 1986, 1988; Fay, 1989). Instead, the survey team worked in the two other large areas of forest. In the first, between Bambio and Bangui (Figure 2), a new road has resulted in a dramatic increase in hunting pressure. The numbers of all large mammals, especially elephants, have been reduced.

Before our reconnaissance, we were told that few elephants remained in the Bangassou forests (Figure 2), while safari hunters claimed that they had increased. The field team found that there was intense poaching, but that the elephant density was indeed quite high, especially far from human settlements.

Michelmore et al: (1989) estimated that 2200 elephants remained in the forests of CAR, while Fay and Agnagna (1991a) calculated that there were 6200 .

\section{Congo}

\section{Background}

Elephants were found throughout Congo in the 1950s. Since then the road network has been improved, modern firearms have become more common, and elephants have all but disappeared from the savannahs (Barnes, 1987).

Nearly two-thirds of Congo is covered by forest. The southern forests comprise two blocks, which have been heavily logged for the last century. The logging companies are now turning towards the forests that cover the northern half of the country. The human population in the northern forests is very sparse, about one person per sq $\mathrm{km}$.

\section{Results}

The field team visited three widely differing parts of northern Congo (Figure 2): the inundated forests; the remote north-east; and the west near the Gabon frontier.

Elephants were still common on the edge of the swamp forests in north-eastern Congo, at least near Lake Mboukou. The villagers reported seasonal fluctuations in elephant numbers: they moved into the swamp forests in the dry season and left in the wet season. Many old elephant paths showed that the elephant population had once been very abundant, but had been much reduced by poaching.

In the remote north-eastern corner of Congo, elephant numbers along the Ibenga River have decreased significantly in recent years. There was much poaching around Berandjoko, with large quantities of ivory passing through the town of Dongou. Many poachers came south from CAR to hunt elephants. Further west, there were high elephant densities in the forests adjacent to the south-western corner of CAR. This zone of high density spanned the adjacent corners of Cameroon, CAR and Congo.

Elephants were common in the area surveyed in western Congo, between Mbomo and Sembe, especially in the remote forests far from human disturbance. There appeared to be little poaching here compared with other parts of Congo. Even so, elephant densities were lower than on the Gabon side of the frontier, reflecting the fact that, in general, poaching is heavier in Congo than in Gabon.

This reconnaissance confirmed that there 
are still many elephants left in northern Congo: perhaps 40,000 (Michelmore et al., 1989). But the areas of high elephant density accounted for only a small proportion of the potential elephant habitat. Elsewhere elephant numbers had been significantly reduced.

The survey team confirmed that high-powered hunting rifles, automatic weapons and ammunition were abundant in Congo. Ivory poaching was the major activity for many people in the forest zone. Ivory was a major topic of conversation in Brazzaville at the time of this reconnaissance. It was clear that ivory poaching was proceeding on a grand scale in Congo. The expansion of the timber industry into the northern forests and the construction of logging roads will facilitate access by poachers to the last undisturbed elephant populations in Congo.

\section{Zaire}

\section{Background}

Zaire is a huge country, with forests that cover about a million sq $\mathrm{km}$. There are vast expanses of undisturbed forest, which appear to be excellent habitat for elephants. These forests have long been assumed to hold Africa's largest elephant population. For many years there have been reports of very heavy ivory poaching (Barnes, 1987). Between 1979 and 19882648 tonnes of ivory were exported from Zaire (de Meulenaer and Meredith, 1989). This represents the deaths of about 200,000 elephants.

\section{Reconnaissance in western Zaire}

Field-work was concentrated in and around Salonga, Africa's largest national park. The park covers $36,000 \mathrm{sq} \mathrm{km}$ in two separate blocks (Doumenge, 1988; D'Huart, 1988). There were still many elephants within the park, but ivory poachers were very active, especially along the large rivers. Nevertheless, high densities of elephants were still found in some places in both blocks. There were some parts of the northern block from which ele- phants had been eliminated. Outside the park, to the south, intense poaching has eliminated most elephants.

Poaching gangs used motorized canoes on the large rivers to penetrate the remotest forests. They carried automatic weapons (often provided by the army) and were well organized. For example, some had a basecamp downstream of Watsi Kengo. This camp was provisioned by boats from Mbandaka, which is a major commercial centre on the Zaire River. Poachers unloaded the ivory at the base-camp, re-provisioned, and then returned upriver into the park. Meanwhile the ivory was taken down to Mbandaka.

\section{Reconnaissance in eastern Zaire}

Much of the field-work in eastern Zaire was concentrated in and around Maiko National Park, which covers about $10,000 \mathrm{sq} \mathrm{km}$ (Doumenge, 1988). The park was found to be inhabited by many thousands of people: goldpanners and Simba rebels.

Despite heavy poaching, especially by the rebels, there were still many elephants in Maiko. But most elephant footprints that were seen were of small animals, suggesting that the larger ones had been shot out.

\section{Discussion}

For the last three decades, and especially during the civil war, elephants have been killed in large numbers (Barnes, 1987). Elephants are killed by villagers who have always hunted them, by villagers commissioned by businessmen or officials to obtain ivory, or by wellorganized gangs. This study confirmed that large numbers of elephants have been killed even in the remotest forests of Maiko and Salonga. Biologists report the absence of elephants from areas of remote forest where they used to occur in the 1970s (Rollais, 1979; T. Kano, pers. comm.; S. Kuroda, pers. comm.). The forests of Zaire may have once held vast numbers of elephants, but they do so no longer. Michelmore et al. (1989) estimated 87,000 elephants remaining in the forests of Zaire, but this did not account for the areas of 
forest, of unknown extent, where elephants no longer occur. Alers et al. (in press) made a different set of assumptions to give an estimate of 64,000 .

The large quantities of ivory known to have left the country in recent years confirm the findings on the ground of widespread and intense elephant poaching. Zaire accounted for 36 per cent of the raw ivory exported from Africa during the 1980s; most of this was illegally obtained (de Meulenaer and Meredith, 1989). Some powerful figures in the government are alleged to have been involved in ivory trafficking (Douglas-Hamilton, 1979; D'Huart, 1988).

\section{Surveys made in the equatorial forests before 1989}

\section{Equatorial Guinea}

Elephants exist only on the mainland of Rio Muni, about half of which is covered by forest. A brief reconnaissance was made by Alers and Blom (1988) in June 1988 when they reported very few elephants in the northern half of the country. It is in the southern half of the country, where the human population is less dense, that elephants are found. There are three particularly important areas: one in the southwestern mountains and two in the south-east. Even so, the total number of elephants in Equatorial Guinea is unlikely to exceed 500 (Michelmore et al., 1989). There is a little elephant poaching. Rifles are scarce, and even shotguns are in short supply.

\section{Gabon}

Three-quarters of Gabon is covered by forest and huge expanses remain undisturbed, especially in the north-east (Barnes et al., 1991). The deforestation rate is the lowest in Africa (FAO/UNEP, 1981). There are large populations of chimpanzees and lowland gorillas (Tutin and Fernandez, 1984), and there is great potential for general conservation (Tutin and Fernandez, 1987; McShane, 1990).

Elephants are both widespread and abun- dant (WCI, 1989; Barnes et al., 1991). If the population estimate of 69,000 (Michelmore et al., 1989) is correct, then Gabon holds one of the continent's largest elephant populations. Poaching by villagers is widespread, but on a small scale, and probably has little effect on elephant numbers. Although there was one poaching ring operating in 1987 and 1988, organized commercial poaching for ivory has not taken hold as it has in neighbouring countries.

\section{General discussion}

The data collected during this survey were used by Michelmore et al. (1989) to calculate that there may be about 200,000 elephants in the central African forests. This figure is based on rather sparse data and must be viewed with caution. Nevertheless, it is the first estimate based on data from the field and it is considerably less than previous estimates. For example, Burrill and Douglas-Hamilton (1987) calculated that there were 495,000 elephants remaining in the equatorial forests.

About one-third of the remaining forest elephants is to be found in Gabon where they are still abundant and widespread. Zaire may account for another third of the forest elephant population; we recognize that this could be an optimistic assessment because Zaire has lost very large numbers of elephants over a period of three decades. The remaining third is to be found in the forests of Cameroon, CAR, Equatorial Guinea, and Congo.

The field teams found little evidence, except for parts of Cameroon, that elephants are threatened by habitat loss. But in four of the six countries elephant numbers were declining at the time of the reconnaissance because of poaching for ivory. No previous surveys had been done before this one, and so there are no data on elephant numbers and distribution to compare with the information collected in 1989 to estimate trends. However, the widespread reports of reduced elephant numbers, and of elephants being eliminated from some forests, point towards significant declines in elephant abundance. This conclu- 
sion is supported by the comparison between poached and unpoached populations of forest elephants (Michelmore et al., 1989): ivory poaching may have reduced forest elephant populations by 50 per cent or more.

The distinction must be made between small-scale elephant hunting by villagers and organized commercial poaching for ivory. The rural population has always hunted elephants and one or two elephants may be killed per village per annum by this type of hunting (Barnes and Jensen, unpublished; S. A. Lahm, pers. comm.). In view of the sparse distribution of the human population, it is probably not a very important form of predation.

It is the organized hunting by rings of poachers and ivory traffickers, rather than small-scale hunting by peasants, that presents the greatest threat at the moment. During the 1970 s and 1980s this type of poaching was common in Cameroon, CAR, Congo, and Zaire. In each of these countries, rumours were common that corrupt officials and prominent businessmen were implicated in organizing the killing of elephants and smuggling of ivory. Often they were alleged to supply arms and ammunition. The availability of firearms is an important factor in determining the level of ivory poaching (DouglasHamilton, 1983, 1987). We found that automatic weapons were widely available in the countries where ivory poaching was rampant. In contrast, none was seen in Gabon or Equatorial Guinea.

This reconnaissance represents the first field assessment of the status of elephants in the equatorial forests. More intensive surveys are planned to produce detailed assessments of the status of forest elephants so that effective management plans can be drawn up for each country.

\section{Acknowledgments}

The forest elephant reconnaissance was carried out by Wildife Conservation International under contract to the World Wildlife Fund for Nature (Project no. 3882.05), as part of the EEC/WWF African Elephant Programme. In Cameroon we thank M. Tandeau de Marsac, Chef de Departement de Foresterie, and the Secretaire General du Centre
Universitaire de Dschang for making available a university vehicle, and M. D. Momo, Directeur de la Faune et des Parcs Nationaux. In Congo we thank Dr Ndinga Assitou, M. J. Mokoko Ikonga, and M. D. N'Sosso for the collaboration provided by the Ministere de l'Economie Forestiere. In Zaire we thank Cit. Mankoto ma Mbaelele for the collaboration of IZCN, and Dr H. Mertens, Mr P.H. TowersPicton, M. C. Froidbise, and Mr C. Trapman. We thank Professor Sir James Beament and Dr S. K. Eltringham for providing facilities in the Department of Applied Biology, University of Cambridge.

\section{References}

Alers, M.P.T. and Blom, A. 1988. Elephants and Apes of Rio Muni: Report of a First Mission to Rio Muni (Equatorial Guinea). Unpubl. manuscript. Wildlife Conservation International.

Alers, M.P.T., Blom, A., Sikubwabo Kiyengo, C., Masunda, T. and Barnes, R.F.W. 1992. Preliminary assessment of the status of the forest elephant in Zaire. Afr. J. Ecol. 30, in press.

Barnes, R.F.W. 1987. A review of the status of elephants in the rain forests of central Africa. In African Elephant Database Project: Final Report (eds A. Burrill and I. Douglas-Hamilton), pp. 41-46. UNEP/GRID, Nairobi.

Barnes, R.F.W. and Jensen, K.L. 1987. How to count elephants in forests. AERSG Technical Bulletin, 1, $1-6$.

Barnes, R.F.W., Barnes, K.L., Alers, M.P.T, and Blom, A. 1991. Man determines the distribution of elephants in the rain forests of north-eastern Gabon. Afr. J. Ecol. 29, 54-63.

Burrill, A. and Douglas-Hamilton, I. 1987. African Elephant Database Project: Final Report. UNEP/GEMS, Nairobi.

Carroll, R.W. 1986. Status of the lowland gorilla and other wildlife in the Dzangha-Sangha region of southwestern Central African Republic. Primate Conservation, 7, 38-41.

Carroll, R.W. 1988. Elephants of the DzanghaSangha dense forest of south-western Central African Republic. Pachyderm, 10, 12-15.

de Meulenaer, T. and Meredith, M. 1989. The ivory trade in Zaire. In The Ivory Trade and the Future of the African Elephant (ed. S. Cobb). International Development Centre, Oxford.

D'Huart, J.P. 1988. Parc National de la Salonga (Equateur, Zaire): conservation et gestion, developpement des Collectivites locales. IUCN, Gland.

Douglas-Hamilton, I. 1979. African Elephant Ivory Trade Final Report to the US Fish \& Wildlife Service. Typescript.

Douglas-Hamilton, I. 1983. Elephants hit by African 
arms race. Pachyderm, 2, 11-13.

Dougląs-Hamilton, I. 1987. African elephants: population trends and their causes. Oryx , 21, 11-24.

Douglas-Hamilton, I., Froment, J.M., Doungoube, G., and Root, J. 1985. Amenagement Faune Republique Centrafricaine. Recensementaerien de la faune dans la zone nord de la Republique Centrafricaine. FAO:CAF/78/006 Document de travail 5.

Doumenge, C. 1988. Rapport National: Zaire. IUCN, Gland.

FAO/UNEP. 1981. Tropical Forest Resources Assessment Project: Forest Resources of Tropical Africa. FAO/ UNEP, Rome.

Fay, J.M. 1989. Partial completion of a census of the lowland gorilla (Gorilla g. gorilla [Savage and Wyman]) in south-western Central African Republic. Mammalia, 53, 203-215.

Fay, J.M. and Agnagna, M. 1991a. Forest elephant populations in the Central African Republic and Congo. Pachyderm, 14, 3-19.

Fay, J.M. and Agnagna, M. 1991b. A population survey of forest elephants (Loxodonta africana cyclotis) in northern Congo. Afr. J. Ecol. 29, 177-187.

Froment, J.M. 1985 Exploitation des Elephants Republique Centrafricaine. Document de terrain No. 1, CAF/78/006, FAO.

Gartlan, S. 1989. Conservation et Utilisation rationelle des Ecosystemes Forestiers en Afrique Centrale: Cameroun. IUCN, Gland.

Luxmoore, R., Caldwell, J. and Hithersay, L. 1989. The volume of raw ivory entering international trade from African producing countries from 1979 to 1988. In The Ivory Trade and the Future of the African Elephant (ed. S. Cobb). International Development Centre, Oxford.

McShane, T.O. 1990. Conservation before the crisis an opportunity in Gabon. Oryx, 24, 9-14.

Martin, R.B. 1986. Establishment of African ivory export quotas and associated control procedures. In African Elephants, CITES and the Ivory Trade (R. B. Martin, J. R. Caldwell and J. G. Barzdo), pp. 1-100. CITES, Laușanne.
Michelmore, F, Beardsley, K., Barnes, R.F.W. and Douglas-Hamilton, I. 1989. Elephant population estimates for the central African forests. In The Ivory Trade and the Future of the African Elephant (ed. S. Cobb). International Development Centre, Oxford.

Parker, I.S.C. 1979. The Ivory Trade. Report to US Fish \& Wildlife Service. Typescript.

Pinglo, F. 1988. Rapport National: Republique Centrafricaine. IUCN, Gland.

Rollais, G. 1979. Note sur la situation de l'elephant en Republique du Zaire. Unpubl. manuscript.

Tutin, C.E.G. and Fernandez, M. 1984. Nationwide census of gorilla (Gorilla g. gorilla) and chimpanzee (Pan t. troglodytes) populations in Gabon. American Journal of Primatology, 6, 313-336.

Tutin, C.E.G, and Fernandez, M. 1987. Gabon: a fragile sanctuary. Primate Conservation, 8, 160-161.

WCI. 1989. Rapport preliminaire sur l'inventaire de l'elephant des forets au Gabon. Unpubl. manuscript. Wildlife Conservation International, New York.

White, F. 1983. The Vegetation of Africa. UNESCO, Paris.

R. F. W. Barnes, Department of Biology 0116, La Jolla, San Diego, California 92093-0116, USA.

M. Agnagna, Direction de la Conservation de la Faune, BP 2153, Brazzaville, Congo.

M. P. T. Alers, BP 4, Tai, Cote d'Ivoire.

A. Blom, Epulu via Mambasa, PO Box 21285, Nairobi, Kenya.

G. Doungoube, BP 1360, Bangui, Central African Republic.

J. M. Fay, Wildlife Conservation International, Bronx Zoo, Bronx, New York 10460, USA.

T. Masunda, IZCN, BP 868 Kin 1, Kinshasa, Zaire.

J.-C. Ndo Nkoumou, Direction de la Faune et des Parcs Nationaux, Secretariat du Tourisme, Yaounde, Cameroon.

C. Sikubwabo Kiyengo, Epulu via Mambasa, PO Box 21285, Nairobi, Kenya.

M. Tchamba, BP 336, Maroua, Cameroon. 